\title{
La documentación como servicio público: estudios en homenaje a Adelaida Román (Luis Rodríguez-Yunta y Elea Giménez-Toledo, coords.)
}

\author{
Por Fernanda Peset
}

Peset, Fernanda. "La documentación como servicio público: estudios en homenaje a Adelaida Román (Luis RodríguezYunta y Elea Giménez-Toledo, coords.)". Reseña de libro. El profesional de la información, 2010, marzo-abril, v. 19, n. 2, pp. 217-218.

DOI: $10.3145 /$ epi.2010.mar.16

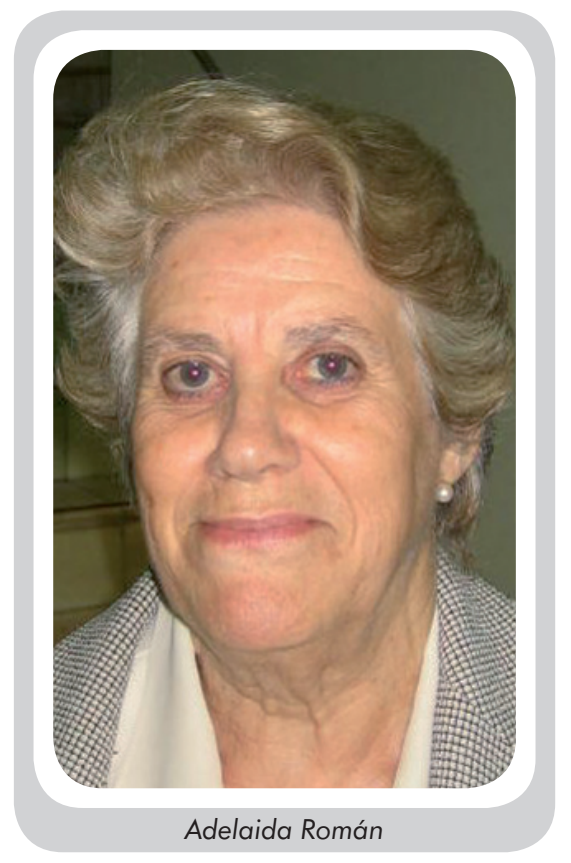

ES DIFÍCIL SABER con qué debes quedarte al leer este homenaje. Estamos tan acostumbrados a digerir -y digo bien, digerir- bibliografía profesional y científica para nuestros trabajos que cuando tenemos entre las manos un libro de estas características nuestra escala de valores se altera.

El libro homenaje a Adelaida Román no es una simple recopilación de textos editados conjuntamente para hacer honor a su carrera. Desde luego que no faltan los estudios científicos en él. Se pueden identificar algunos de los campos actuales de investigación de la información y la documentación científica. Por un lado, la reflexión sobre el control del lenguaje de Moreiro-González, MoratoLara y Sánchez-Cuadrado, o la de Villagrá-Rubio; cuestiones de formación por Tejada-Artigas y Meyriat; textos relacionados con el trabajo con revistas, como el de Abejón-Peña, o el de Cetto y Alonso-Gamboa; del mismo modo encontramos textos sobre los hábitos de los usuarios de información, cómo y quiénes la consumen, de Paz Fernández y de Giménez-Toledo y Rubio-Liniers; por último, los que abordan la difusión de la ciencia y las bases de datos, como el de Anta-Cabreros, el de SorliRojo y Mochón-Bezares, o el de Rodríguez-Yunta.

Hay que destacar que se exponen asuntos de interés no sólo para el área de la información y documentación sino también para todas las áreas científicas. El Cindoc nació en el seno del Csic para ayudar al avance científico general. Y por las materias que trata este homenaje consigue una propuesta de interés para cualquier investigador. $\mathrm{Al} \mathrm{cu}-$ brir cuestiones como la evaluación de la ciencia, la transmisión de conocimiento mediante las revistas, los indicadores científicos o los productos que afectan a todas las disciplinas, tales como Latindex, resulta un compendio de trabajos de gran ayuda y actualidad.

En estos momentos la reflexión sobre estos temas se encuentra en plena efervescencia. Uno de los orígenes de nuestra disciplina es la

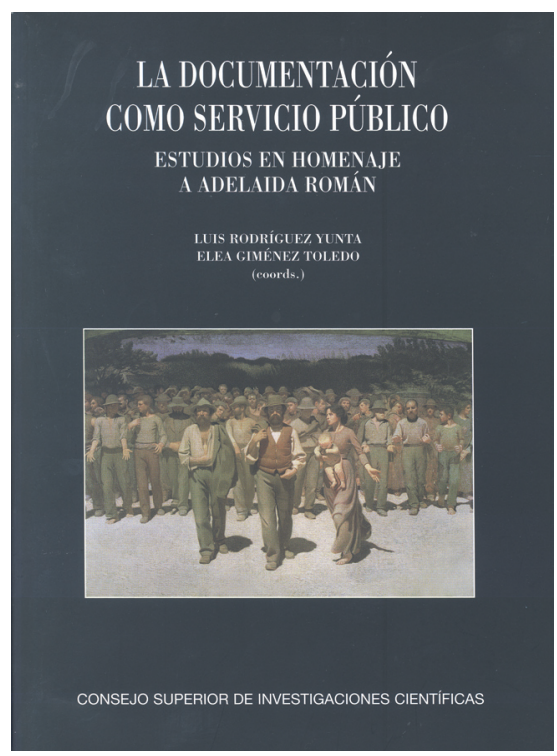

Rodríguez-Yunta, Luis; Giménez-Toledo, Elea (coords.). La documentación como servicio público: estudios en homenaje a Adelaida Román. Madrid: Servicio de Publicaciones del Consejo Superior de Investigaciones Científicas, 2009.

documentación científica, que ha derivado en ocasiones en estudios sobre la comunicación científica.

Recientemente, en España, el investigador se ha visto inmerso en procesos continuos de evaluación y certificación. La aparición de las agencias de acreditación, así como la insistencia en transferir el conocimiento científico hacia la socie- 
dad han colocado nuestro saber en una situación privilegiada. Ahora los productos derivados de nuestro trabajo, como los rankings de revistas o las bases de datos científicas son vitales para la carrera profesional de todos los investigadores $\mathrm{y}$ docentes españoles.

\section{Profesión y su historia}

El libro reseñado no sólo destaca por la oportunidad de los temas. Cabe también referir que los estudios están escritos por los propios protagonistas de la acción: quienes confeccionan el Latindex, quienes convivieron con la homenajeada... Y por ello nos ofrecen información de primera mano y aportan en sus respectivos análisis documentos inéditos, informes privados o enlaces de un interés sobresaliente para el lector.

\section{"La bibliografía explica a grandes rasgos cómo deben ser las cosas, pero no cómo son en realidad"}

Resultan muy interesantes los estudios de acercamiento histórico. Será por llevar muchos años en esta apasionante disciplina, pero creo que es un atrevimiento delicioso que alguien escriba sobre los inicios de nuestra profesión en España. Creo que éste es un documento ilustrativo. Quienes debemos formar a los jóvenes nos enfrentamos con la dificultad de explicarles por qué nuestra profesión se encuentra en el punto de evolución en que se encuentra. No es fácil. Gracias a las nuevas tecnologías y al extenso conocimiento que la Web ofrece con facilidad, los referentes actuales son los avances en países como Estados Unidos, Inglaterra y los países nórdicos. Y España no está a su nivel. No existen actualmente demasiados productos innovadores o una masa crítica de contenidos en nuestro idioma. Y este homenaje viene a ilustrarnos, a dejar constancia de las dificultades de unos inicios no demasiado lejanos en el tiempo.

Lo cierto es que cuando alguien se interesa y se acerca a los productos de nuestra profesión tiene en mente unas expectativas que no siempre coinciden con la realidad. Más aún si se trata de un joven estudiante que tiene un acceso al conocimiento de su profesión únicamente teórico, mediante manuales. La bibliografía explica a grandes rasgos cómo deben ser las cosas, pero no cómo son en realidad. Además, el idealismo es un don con el que cuentan sólo algunos hombres, pero que aparece con frecuencia entre los estudiantes, con unas apremiantes ganas de trabajar. Jóvenes a quienes les cuesta entender que no contemos en España con los mismos resultados que en otros países y que el avance en las profesiones se produce a base de esfuerzos continuados. Y es que las profesiones se van construyendo entre todos los que las integran: profesionales, docentes e investigadores en nuestro caso. La aportación de cada uno de ellos es esencial para su progreso, especialmente cuando en España la inversión económica en información no es uno de los aspectos que destacan ni en el sector público ni en el privado. Por esa razón es importante cada uno de los empujes de las personas, y cada una de las personas que trabajan y han trabajado en este sector en España.

Esto es lo que algunos de los trabajos del libro destilan en este homenaje: el factor humano. Leyendo sus páginas podemos imaginarnos el encono, la ilusión y el esfuerzo tenaz de cada una de las personas que trabajaban en instituciones señeras como el Cindoc. Y este es el caso de Adelaida Román, referente en nuestra profesión.

En definitiva se trata de una publicación que reúne trabajos de gran calidad y que llegan a conclusiones sorprendentes en el contexto de la obra. Véase, como ejemplo, la visión general y la propuesta de un modelo de evaluación de la actividad científica del área de historia y humanidades.

En conclusión, por éstas y por varias otras razones es un libro de imprescindible lectura para los que trabajamos en este sector. Un libro que por su contenido y por su forma se disfruta leyendo y aprendiendo.

Fernanda Peset, Universidad Politécnica de Valencia. mpesetm@upv.es

\section{Suscripción EPI sólo online}

Pensando sobre todo en los posibles suscriptores latinoamericanos, ya no es obligatorio pagar la suscripción impresa de EPI para acceder a la online.

EPI se ofrece a instituciones en suscripción "sólo online"

a un precio considerablemente más reducido (90 euros/año), puesto que en esta modalidad no hay que cubrir los gastos de imprenta ni de correo postal. 